\title{
PAVO CRISTATUS FEATHER POWDER AS AN ECO-FRIENDLY AND LOW COST MATERIAL FOR MITIGATION OF Pb(II) IONS FROM WATER
}

\author{
Suman Saini ${ }^{1{ }^{*}}$, Jyoti Chawla ${ }^{2 a}$, Rajeev Kumar ${ }^{3 \mathrm{a}}$ and Inderpreet Kaur ${ }^{4 b^{*}}$
}

\author{
anav Rachna International Institute of Research and Studies, Faridabad, Haryana, INDIA. Email: \\ suman3996@gmail.com; jyoti.fet@mriu.edu.in²; rajeevkumar.fet@mriu.edu.in ${ }^{3}$ \\ bepartment of Chemistry, Centre for Advanced Studies, Guru Nanak Dev University, Amritsar, Punjab, INDIA. \\ Email: inderpreet11@yahoo.co.in ${ }^{4}$ \\ Corresponding author: suman3996@gmail.com
}

Received: $10^{\text {th }}$ April $2019 \quad$ Accepted: $2^{\text {nd }}$ May 2020

DOI: https://doi.org/10.22452/mjs.vol40no1.1

Published: $28^{\text {th }}$ Feb 2021

\begin{abstract}
Mitigation of $\mathrm{Pb}$ (II) ions from water using economic method is an important research area to combat the pollution due to lead ions $\mathrm{Pb}$ (II) in water as it have severe toxic effects in human beings. In present work, Pristine Pavo Cristatus feather powder (PCFP) has been employed for removal of $\mathrm{Pb}$ (II) ions and the process of adsorption was optimized through four level Box Behnken design (BBD) of response surface methodology (RSM) over a broad range of $\mathrm{pH}$ (3.0-9.0), initial lead ion concentration (20-100 mg/L), contact time (20-180 min) and temperature (297 K to $333 \mathrm{~K}$ ). Different isotherms were applied to confirm the type of adsorption. Langmuir maximum removal efficiency was $121.95 \mathrm{mg} / \mathrm{g}$ for lead ions adsorption onto PCPF at optimal values of $\mathrm{pH} 6$; adsorbent dose $20 \mathrm{mg} / \mathrm{L}$; temperature $303 \mathrm{~K}$ and contact time 120 minutes obtained from batch studies. Pseudo-secondorder reaction model showed good applicability for kinetic studies. Thermodynamic parameters were also evaluated to check feasibility and nature of adsorption. The optimal parameters obtained for maximum $\mathrm{Pb}$ (II) ions adsorption were at $\mathrm{pH}=6.31$, initial $\mathrm{Pb}$ (II) ion $=43.79 \mathrm{mg} / \mathrm{L}$, contact time $=119.51$ minutes and temperature $=59.67{ }^{\circ} \mathrm{C}$. The experimental and predicted values were found to be in good agreement with each other.
\end{abstract}

Keywords: Adsorption, Response surface methodology, Langmuir isotherm model, Lead, Pavo Cristatus feather powder.

\section{INTRODUCTION}

Water pollution because of lead and other metal ions causes serious human health hazards and environmental implications. These heavy metal ions may enter into all living systems including human beings through food, air and water. Small concentrations of these heavy metal ions have severe toxic effects in human beings (Yavuz et al., 2007). In addition, these heavy metal ions may enter into water streams and soil and adversely affect yield, growth and quality of the crops (Garba et al., 2016; Naseem and Tahir, 2001). Pb(II) is noxious metal found in earth's crust. Human activities such as mining, manufacturing and burning fossil fuels are the main reasons behind its occurrence in the environment. Lead poisoning effects in children are irreversible and may lead to brain damage, kidney problems, hyperactivity, juvenile delinquency learning \& behavioral problems and 
impaired hearing (Raikar et al., 2015; Das et al. 2014). Toxicological effects of lead on adults are liver, kidney, reproductive system \& brain damage (Annadurai et al., 2002; Farhan et al., 2013; El-Ashtoukhy et al., 2008). Excessive exposure of lead leads to insomnia, anemia, muscles weakness, irritability, headache and renal damage (Alam et al., 2012; Azouaoua et al., 2013; El-Wakil et al. 2014).

According to Indian standard for drinking water (BIS, 1981), environmental protection agency (EPA, 2008) and world health organization (WHO, 1996) desirable amount of $\mathrm{Pb}$ (II) ions in drinking water are $0.01,0.015 \& 0.05 \mathrm{mg} / \mathrm{L}$ respectively. As per the various investigations in different parts of world, $\mathrm{Pb}$ (II) ions concentration in ground water was found to be more than the permissible levels. Ground water samples from different districts of Punjab, India were found to contain lead more than the permissible value (The Tribune, 2018). As per another report in Business Standard (March, 2018) underground water samples were found to be polluted with high concentration of lead in an e-waste dumping site at Krishna Vihar in Delhi, India. On 7 Jan, 2016, Flint, Michigan, was declared to be in state of emergency due to its drinking water contamination with lead (CNN, 2016). Water samples from a number of Hong Kong's housing estates were found to be contaminated with lead which exceed WHO standards (SCMP, 2015). In Kolkata (India), 150 out of 250 blood samples of kids were tested positive for high levels of lead. Daily use items such as lead pencils, cheap plastic mugs, toys, cheap crayons and colors, wall paints are to be blamed for this lead poisoning (The Times of India, 2013). Annually, painted idols were immersed in rivers and lakes in India which increases the lead levels in water sources (The Wall Street Journal, 2015). As many studies confirm the presence of lead(II) in ground water in Indian as well as global scenario, there is pressing requirement of economic and feasible water treatment methods that local residents can adopt to get water suitable for drinking and cooking purposes.

Adsorption is a time saving, simple and user-friendly method to adsorb of toxic metal ions from solutions (Kyzas et al., 2015). Various adsorbents have been reported in literature for toxic metal ions adsorption from aqueous solutions but their use is restricted because of certain limitations like high cost, poor efficiency and other environmental implications (Akpomie et al., 2013). It is more important and exigent to find cost effective materials for metal ions adsorption. The main aim of the current study was to utilize Pavo Cristatus feather powder (PCFP), an economical material for effective removal of lead ions from water. Pavo Cristatus (Peacock) feathers are widely used in ayurveda to treat diseases like hiccups, vomiting, and respiratory disorder etc. (Kotrannavar et al., 2012). To best of our knowledge, this work is the first to report of application of Pavo Cristatus (Peacock) feathers as an adsorbent for lead mitigation. To increase the effectiveness of the experiment, to reduce process inconsistency, time and overall costs, RSM was used in current study for optimizing the operational variables (Niad et al. 2016; Kamsonlian and Shukla, 2013).

\section{MATERIALS AND METHODS}

\subsection{Chemicals and preparation of solutions}

Lead nitrate, sulphuric acid and sodium hydroxide were of AR grade (E. Merck Ltd., India). Stock solution of lead ions (1000 ppm) was prepared in double 
distilled water. Solutions of concentration (20-100 mg/L) were further prepared. $0.1 \mathrm{~N}$ $\mathrm{HNO}_{3} \& \mathrm{NaOH}$ were taken to alter the $\mathrm{pH}$.

\subsection{Characterization}

Scanning electron microscope (SEM) (JEOL), FTIR spectrophotometer (Shimadzu), energy dispersive x-ray spectroscopy (EDX) \& BET surface analyzer (Quanta chrome Autosorb) were used to analyze the textural, elemental composition, molecular structure \& surface properties, respectively of the adsorbent.

\subsection{Preparation of Pavo Cristatus feather powder}

Pavo Cristatus feather were purchased from ayurvedic shop in local market, Gurugram, Haryana (India), washed thoroughly and dried at $100{ }^{\circ} \mathrm{C}$ till

$$
q_{e}=\left(C_{o}-C_{e}\right) V / M
$$

$C_{0}=$ Initial concentration of $\mathrm{Pb}(\mathrm{II})(\mathrm{mg} / \mathrm{L})$,

$C_{e}=$ Final concentration of $\mathrm{Pb}(\mathrm{II})(\mathrm{mg} / \mathrm{L})$,

$q_{e}=$ Concentration of lead adsorbed per unit mass of PPCF $(\mathrm{mg} / \mathrm{g})$,

$V=$ Volume of $\mathrm{Pb}(\mathrm{II})$ solution (L), $M=$ Mass of adsorbent, PPCF (g).

\section{RESULTS AND DISCUSSION}

\subsection{Characterization of Pavo Cristatus feather}

\subsubsection{SEM \& EDX analysis}

The surface topography of PPCF was studied by using SEM technique $\&$ the SEM images obtained before \& after $\mathrm{Pb}$ (II) adsorption at $\mathrm{x} 1000$ magnification are given in Figure 1. The adsorbent shows a porous and irregular structure with vacant sites in Figure 1 (a). In Figure 1(b), it can be observed that vacant sites are filled by $\mathrm{Pb}$ (II) ions non-uniformly. So, it can be constant weight was obtained. Washed and dried feathers were powdered to fine powder using mechanical grinder and stored in desiccator until used for adsorption studies.

\section{$2.4 \quad$ Batch studies}

The experiments were performed through shaking PPCF material with lead ions solution of desired concentration at $150 \mathrm{rpm}$. After shaking the bottles, PPCF was separated through filter paper. The remaining amount of lead in filtrate was determined by atomic absorption spectrophotometer (AA-6200, Shimadzu). Before each analysis, calibration of instrument was performed with standards supplied with instrument. The concentration of lead ions adsorbed per unit mass of adsorbent ( $q_{e}$ in $\mathrm{mg} / \mathrm{g}$ ) was determined by following equation:

concluded that the surface of PPCF has changed to a significant extent after adsorption of lead ions.

EDX analysis of PPCF before \& after lead adsorption is given in Figure 1 and the elemental composition of the adsorbent so obtained is summarized in Figure 1 (c) \& (d). EDX spectrum of PPCF (Figure 1c) did not display any characteristic peak for lead ions. However, PPCF after adsorption of lead ions display an additional peaks of $\mathrm{Pb}(\mathrm{II})$ at 2.4 and $10.5 \mathrm{KeV}$ in EDX spectra (Figure 1d) which is displayed as $1.93 \% \quad \mathrm{~Pb}$ (II) accumulation. 


\subsubsection{BET studies}

Specific surface area $\&$ pore size of PPCF was calculated through $\mathrm{N}_{2}$ adsorption at $77 \mathrm{~K}$. The BET (Brunauer-Emmett and Teller) model was applied on nitrogen adsorption isotherm to determine the total

(a)

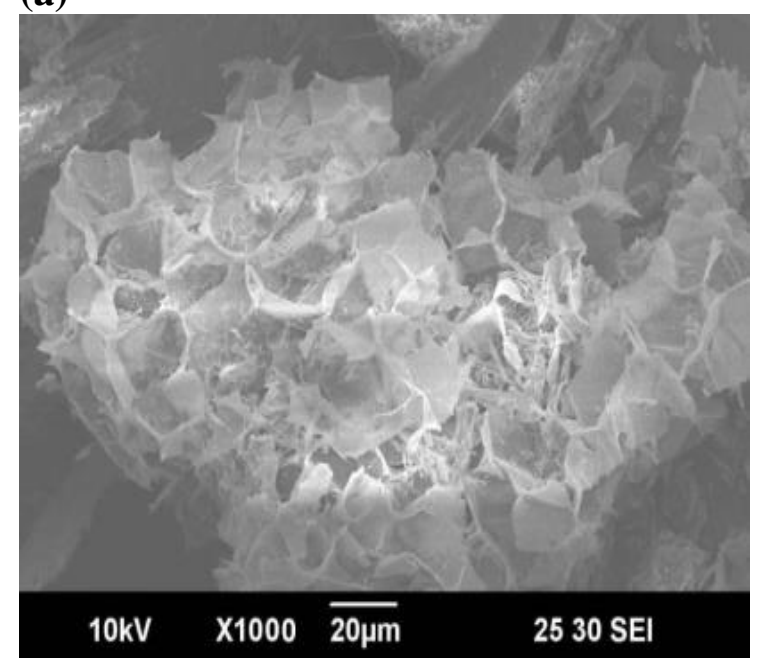

specific surface area (Brunauer et al. 1938). The surface area and pore diameter were observed to be $12.89 \mathrm{~m}^{2} / \mathrm{g}$ and $4.6 \mathrm{~nm}$, respectively. The observed pore diameter was in the range of mesopores $(2-50 \mathrm{~nm})$ which was in favour of adsorption of lead ions on PPCF surface.

(b)

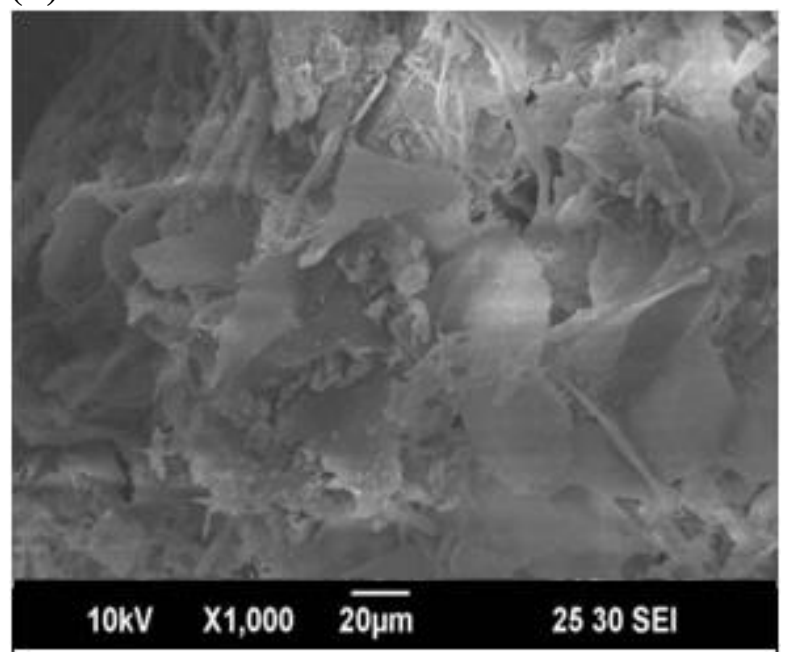

(c)

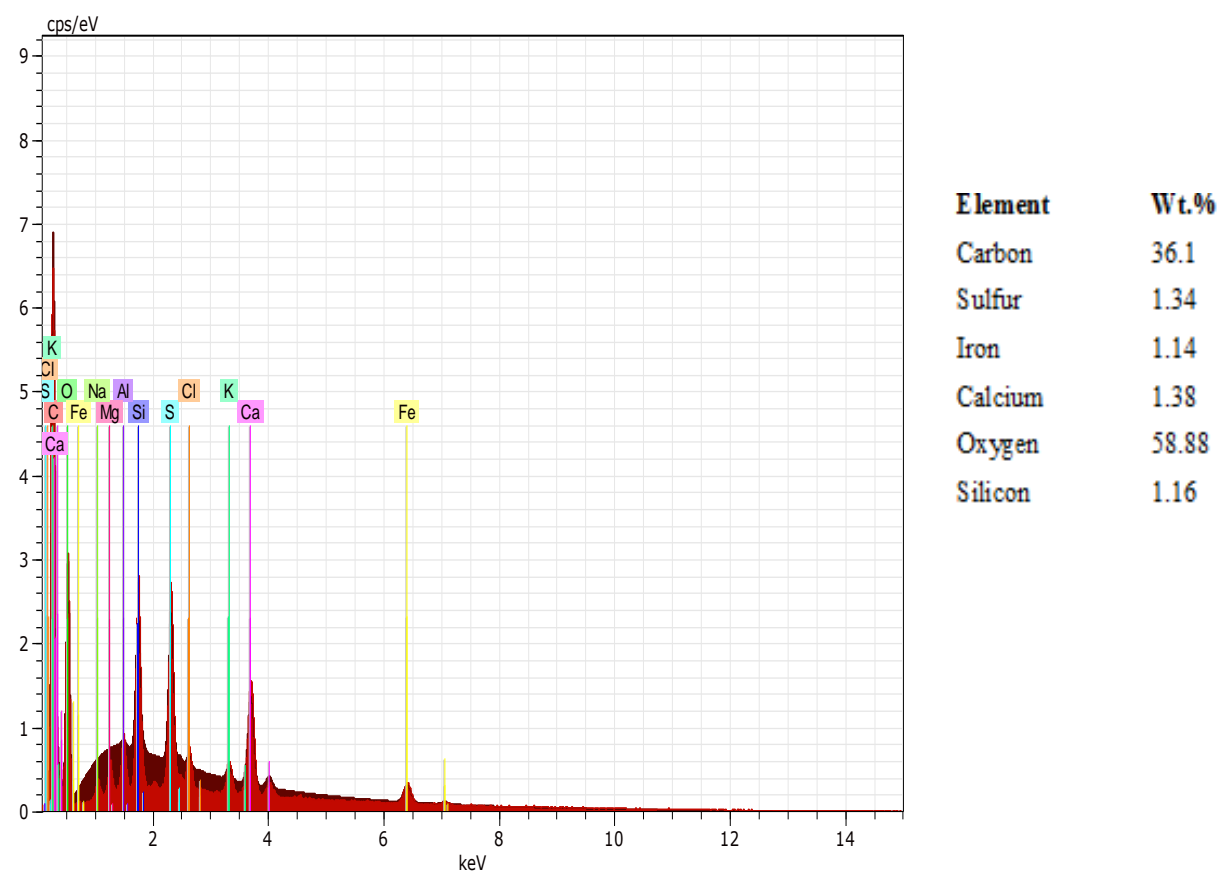


(d)

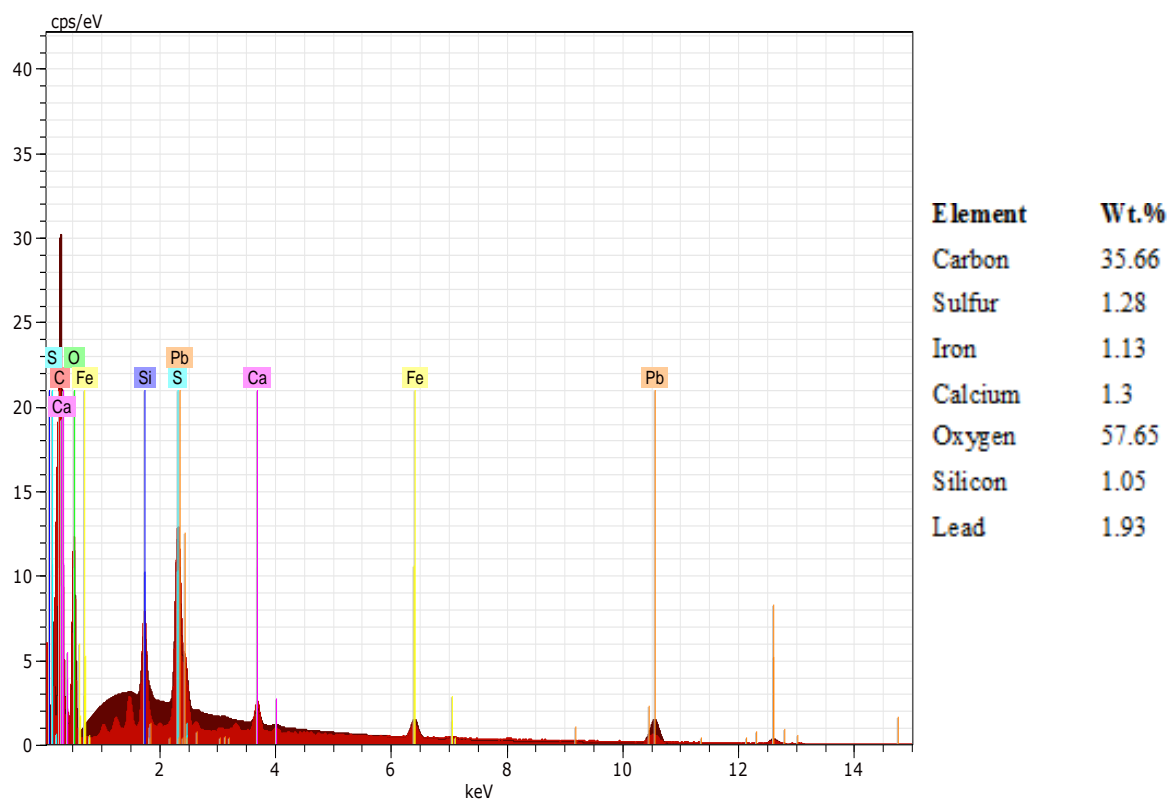

Figure 1. SEM and EDX images of adsorbents (a) Pavo Cristatus feather powder (PCFP) (b) Pavo Cristatus feather powder loaded with lead ions (c) Pavo Cristatus feather powder and (d) Pavo Cristatus feather powder loaded with lead ions

\subsubsection{FTIR analysis}

The FTIR analysis of the adsorbent, PPCF was carried out before \& after lead adsorption. FTIR spectra of PPCF shows peaks at 1643,1450 , and $1373 \mathrm{~cm}^{-1}$ that may be ascribed due to $\mathrm{C}=\mathrm{O}$ stretching vibration, asymmetric stretching vibration of $-\mathrm{CH}_{3}$ and $-\mathrm{CH}_{2}$ \& $\mathrm{C}-\mathrm{O}$ symmetric stretching vibrations of $-\mathrm{COOH}$, respectively. FTIR spectra of PPCF show a new peak at $732.95 \mathrm{~cm}^{-1}$ after adsorption of bivalent lead ions, which indicated the formation of $\mathrm{Pb}-\mathrm{O}$ bond. Also the intensity of adsorption band at $1373 \mathrm{~cm}^{-1}$ was decreased and shifted to $1363 \mathrm{~cm}^{-1}$ (Figure 2). The appearance of new peak confirmed the chemical adsorption due to the formation of new chemical bond between metal ions and carboxylate group generated by the loss of proton on the surface.

\subsection{Adsorption studies}

\subsubsection{Effect of $\mathrm{pH}$}

The study was carried out in the $\mathrm{pH}$ range of 1-9. Adsorption of lead on PCFP was found to increase as $\mathrm{pH}$ was increased from 1 to 6 (Figure 3a). At higher $\mathrm{pH}$, lead ions were precipitated as a result of hydroxides formation. The optimal $\mathrm{pH}$ for maximum adsorption was found to be 6 .

\subsubsection{Effect of initial concentration}

The adsorption efficiencies of the PCFP at different concentration of lead ions (20 to 100 ppm) are given in Figure $3 \mathrm{~b}$. The removal percentage decreased with increase in $\mathrm{Pb}$ (II) concentration. At the low ion concentration, utmost ions interact with the adsorption sites leading to maximum 
adsorption in the solution. However, more lead ions may be present at higher concentration without being adsorbed because of saturation of the active sites. 60 ppm concentration was taken for consequent experiments.

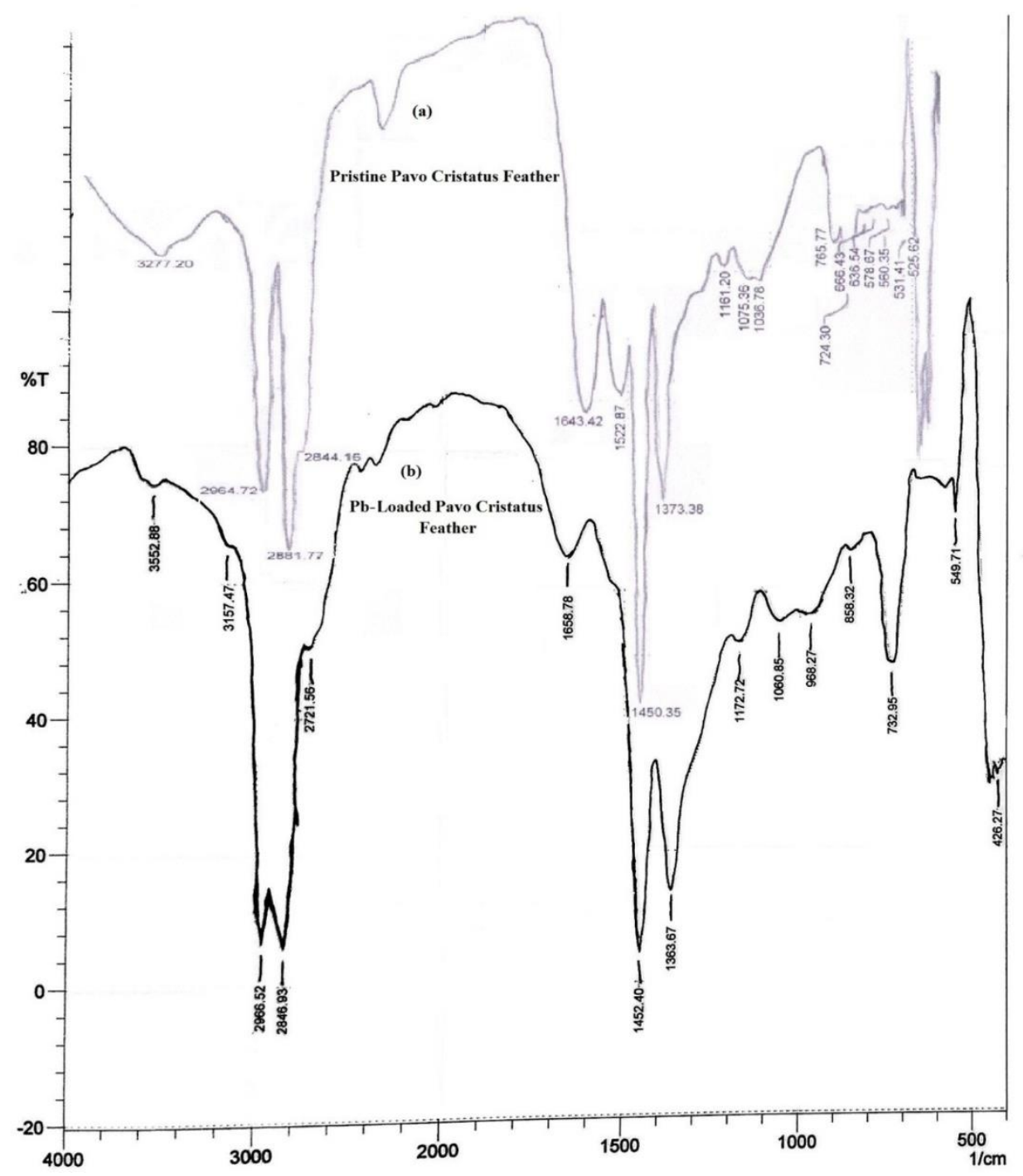

Figure 2. IR spectra of Pavo Cristatus feather powder and Pavo Cristatus feather powder loaded with lead ions

\subsubsection{Effect of adsorbent dose}

Adsorbent dose was taken from 10 to $50 \mathrm{mg} / \mathrm{L}$ under appropriate set of conditions i.e. initial concentration $=60$ ppm; $\mathrm{pH}=6 ;$ Temperature $=303 \mathrm{~K}$; Contact time $=120$ minutes. Maximum $\mathrm{Pb}$ (II) ion removal was found at $20 \mathrm{mg} / \mathrm{L}$ of PPCF and after that increase in dosage did not show any remarkable change in removal efficiency (Figure 3c). This might be owing to the saturation of adsorption sites on PPCF surface. Therefore, $20 \mathrm{mg} / \mathrm{L}$ was taken as optimized dose for all experiments.

\subsubsection{Effect of contact time}

The lead ions adsorption increased with increase in contact time at $\mathrm{pH} 6$ for a fixed concentration of lead ion; fixed adsorbent dose; $303 \mathrm{~K}$ temperature and then become almost constant after 120 minutes. Studies showed that equilibrium was 
attained at $120 \mathrm{~min} \&$ was taken for the later experiments to make certain that equilibrium is well attained.

\subsubsection{Effect of temperature}

The lead ions adsorption by PCFP was performed within the temperature range of $297 \mathrm{~K}$ to $333 \mathrm{~K}$ with other optimized adsorption conditions i.e, $\mathrm{pH}=6$; initial concentration $=60 \mathrm{ppm}$; adsorbent dose $=20 \mathrm{mg} / \mathrm{L} ;$ contact time $=120$ minutes. The lead ions adsorption increased with increase in temperature which might be attributed to increase in the movability of metal ions \& interaction of ions in solutions with the adsorption sites of adsorbent.

(a)

(b)
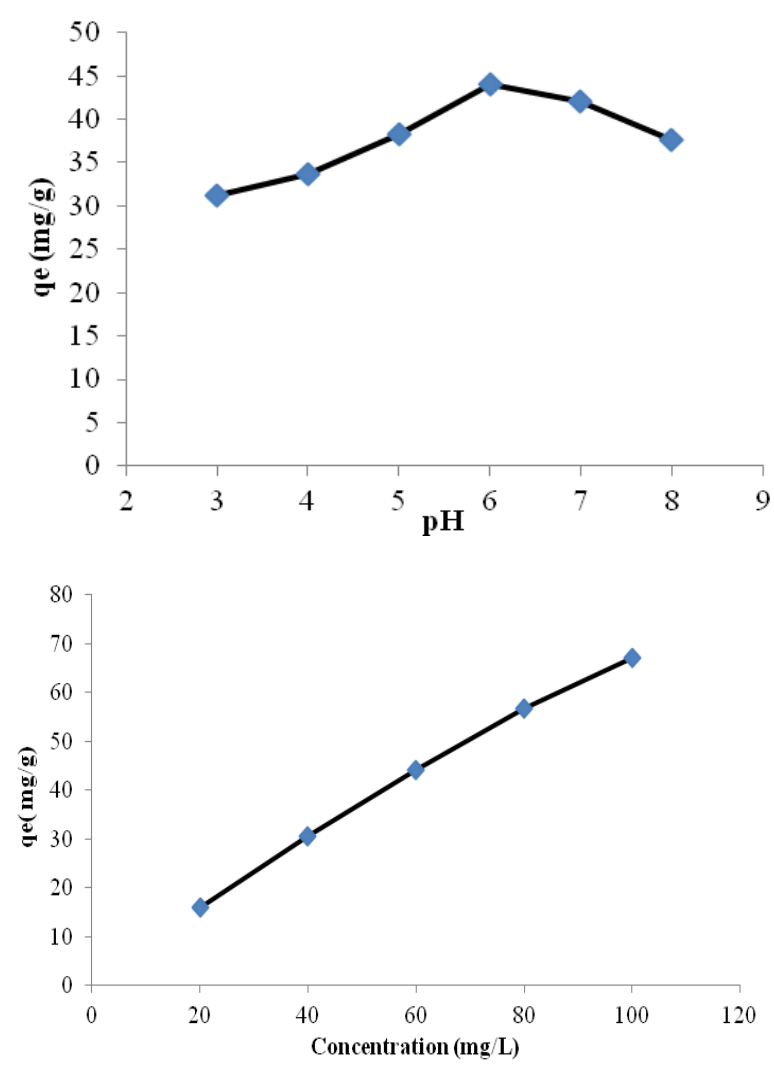

(c)

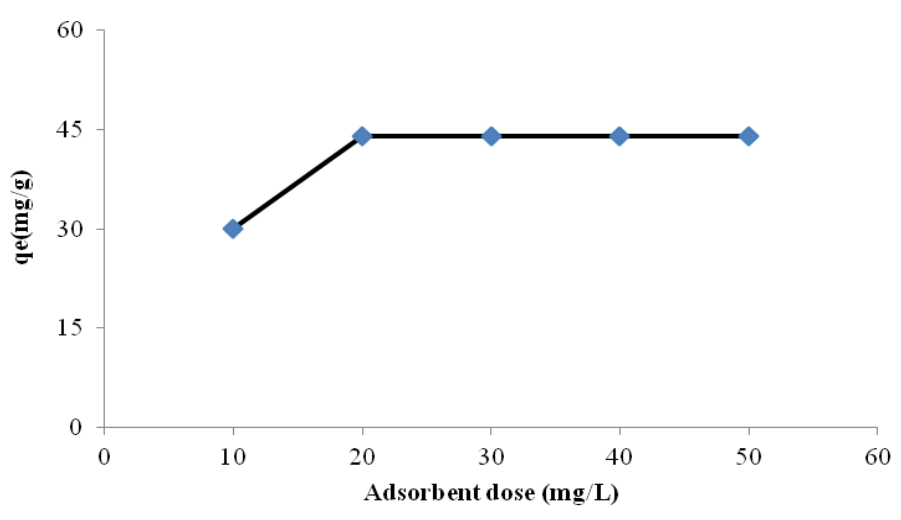

Figure 3. Effect of pH, initial lead ions adsorption, and adsorbent dose on adsorption of lead onto PCFP 


\subsection{Adsorption isotherms}

In the current study, different isotherms were applied to analyze the experimental data $\&$ calculated results are summarized in Table 1.

$$
C_{e} / q_{e}=1 /\left(q_{\max } K_{L}\right)+C_{e} / q_{\max }
$$

Where $C_{e}=$ Equilibrium concentration $(\mathrm{g} / \mathrm{L}), q_{e}=$ Amount of adsorbate at equilibrium $(\mathrm{mg} / \mathrm{g}), q_{\max }=$ Adsorption capability $(\mathrm{mg} / \mathrm{g}), \quad K_{L}=$ Constant $(\mathrm{L} / \mathrm{mg})$. The value of $q_{\max } \& K_{L}$ is calculated from the Langmuir linear plot $C_{e}$ versus $C_{e} / q_{e}$ (Figure 4(a)). In present work,

\subsubsection{The Langmuir isotherm}

Linear form of Langmuir isotherm can be represented as follows:
Langmuir maximum adsorption capacity $\left(q_{\max }\right)$ and equilibrium constant were $121.95 \mathrm{mg} / \mathrm{g} \& 0.0371 \mathrm{l} / \mathrm{mg}$ respectively (Table 1). Dimensionless separation constant $\left(R_{L}\right)$ is used to determine the favorability of the isotherm. Equilibrium parameter can be represented as follows:

$$
R_{L}=1 /\left(1+K_{L} C_{o}\right)
$$

Where $K_{L}=$ Constant $(\mathrm{L} / \mathrm{mg})$ and $C_{0}=$ Initial concentration of $\mathrm{Pb}(\mathrm{II})(\mathrm{g} / \mathrm{L})$. When the value of the $R_{L}$ is 0 , isotherm will be irreversible, for $R_{L}>1$ will be unfavorable, $R_{L}=1$ will be linear and for $0<R_{L}<1$ will be favorable. The $R_{L}$ value calculated by equation (3), $R_{L}$ were found

$$
\ln q_{e}=\ln K+1 / n \ln C_{e}
$$

Where $q_{e}=$ Amount of $\mathrm{Pb}(\mathrm{II})$ adsorbed $(\mathrm{mg} / \mathrm{g}), C_{e}=$ Equilibrium concentration $(\mathrm{g} / \mathrm{L}), K=$ Freundlich constant. The value of $\mathrm{n} \& K$ was calculated from the linear Freundlich plot of $\ln C_{e}$ and $\ln q_{e}$ (Figure 4 (b)). The value of $n$ obtained from slope to be less than 1 and greater than 0 for $\mathrm{Pb}$ (II) ions.

\subsubsection{Freundlich isotherm}

Linear form of Freundlich model can be represented as follows:

was 1.397 which is more than unity and indicated the favourable normal adsorption.

\subsubsection{Temkin isotherm}

Linear form of Temkin isotherm can be represented as follows:

$$
q_{e}=B \ln A+B \ln C_{e}
$$

Where $q_{e}=$ Amount of $\mathrm{Pb}(\mathrm{II})$ adsorbed $(\mathrm{mg} / \mathrm{g} \quad), \quad C_{e}=$ Equilibrium concentration $(\mathrm{g} / \mathrm{L}), A \& B$ are constants.

$$
\left(\mathrm{B}=\mathrm{RT} / \mathrm{b}_{\mathrm{T}}\right)
$$

B can be determined by using following equation:
Where $R=$ Ideal gas constant $(8.314$ $\mathrm{J} / \mathrm{mol} / \mathrm{K}), \mathrm{T}=$ Temperature $(\mathrm{K})$ and $\mathrm{b}_{\mathrm{T}}=$ Temkin isotherm constant. The value of $A$ and $B$ can be determined by linear Temkin plot of $q_{e}$ versus $\ln C_{e}$ Langmuir model,
Freundlich model and Temkin models are summarized in (Table 1). The value of heat of adsorption was $24.626 \mathrm{KJ} / \mathrm{mol}$ which was less than $40 \mathrm{~kJ} / \mathrm{mol}$ and indicated the physical adsorption. 
For lead ions adsorption from water sample Langmuir model was found to be best fitted model rather than Freundlich and Temkin model (Figure 4) as the Langmuir regression correlation coefficient is more close to unity as compared to those observed in Freundlich and Temkin model.

(a)

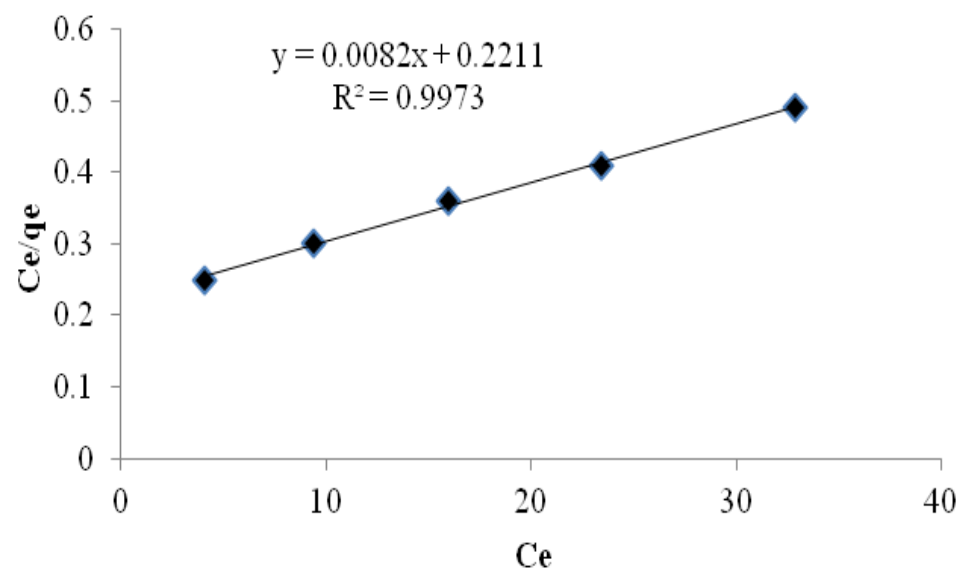

(b)

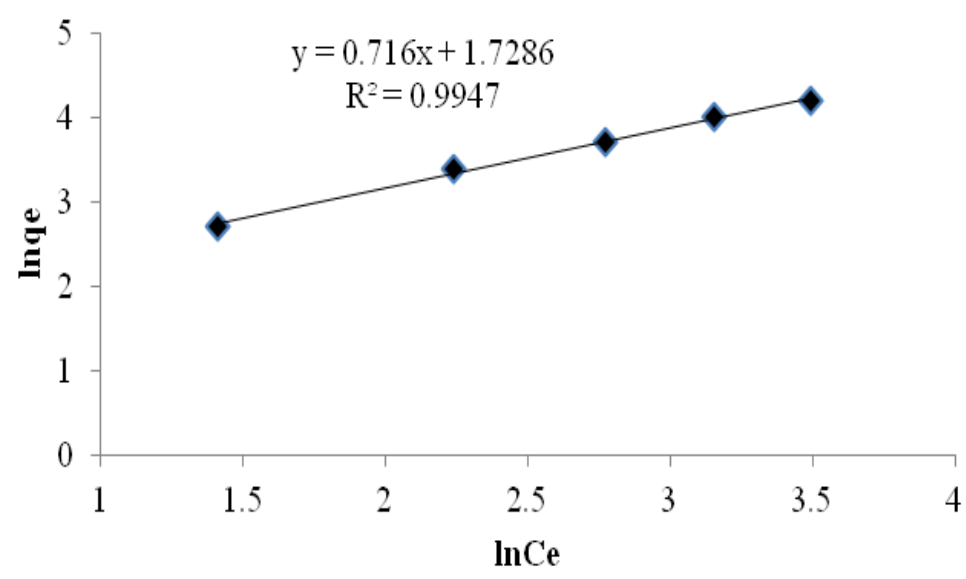

(c)

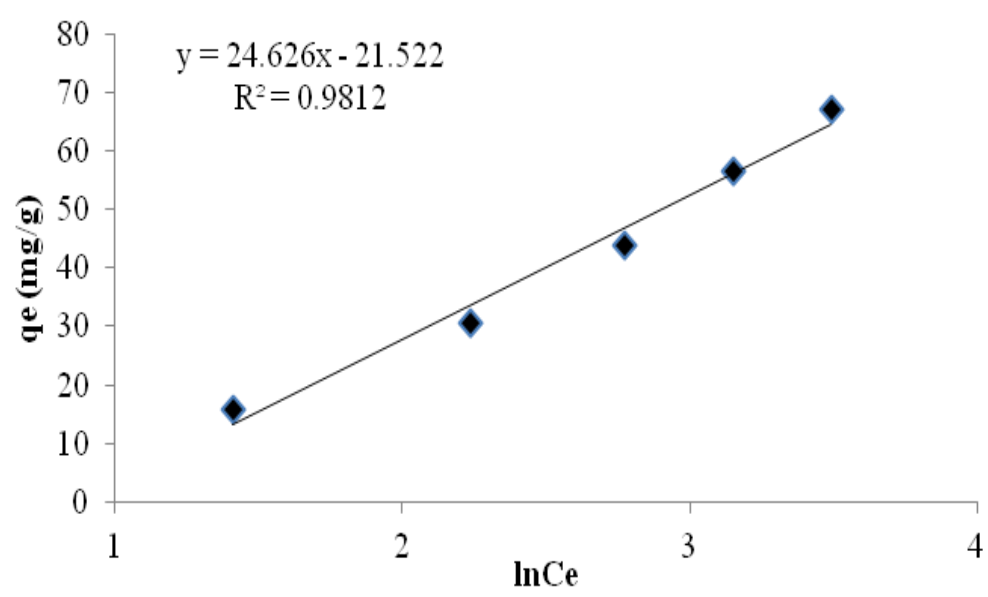

Figure 4. (a) Langmuir isotherm model (b) Freundlich isotherm model (c) Temkin isotherm model for lead ions adsorption onto Pavo Cristatus feather powder 


\subsection{Kinetics of adsorption}

The kinetics of the adsorption can be explained by the following kinetic models.

\subsubsection{Pseudo-first-order kinetic model}

The linear form of the pseudo-first-order model can be expressed as follows:

$$
\ln \left(q_{e}-q_{t}\right)=\ln \left(q_{e}\right)-k_{1} t
$$

Where $q_{e} \quad \& \quad q_{t}$ represent amount of adsorbate $(\mathrm{mg} / \mathrm{g})$ at equilibrium $\&$ at any time t, respectively $\& k_{l}$ is first order rate constant.

\subsubsection{Pseudo-second-order model}

The linear form of the pseudo-second-order kinetic model can be expressed as follows:

$$
t / q_{t}=1 / k_{2} q_{e}^{2}+t / q_{e}
$$

Where $q_{e}$ and $q_{t}$ represent amount of adsorbate $(\mathrm{mg} / \mathrm{g})$ at equilibrium \& at any time t, respectively \& $k_{2}$ is second order rate constant.

The value of $q_{e}$ and $k_{1}$ were calculated from the plots of $\ln \left(q_{e}-q_{t}\right)$ versus $t$ for the pseudo-first-order model. Similarly, the value of $k_{2}$ and $q_{e}$ were determined from the plots of $t / q_{t}$ versus $t$ for pseudo-second-order kinetics respectively (Figure 5).

The calculated kinetic constants \& correlation coefficients for pseudo-firstorder model \& pseudo-second-order-model

$$
\begin{aligned}
K_{c} & =C_{A d} / C_{e} \\
\Delta G^{o} & =-R T \ln K_{c}
\end{aligned}
$$

Where $K_{c}=$ Equilibrium constant, $C_{A C}=$ Equilibrium amount of $\mathrm{Pb}(\mathrm{II})$ ions $(\mathrm{mg} / \mathrm{L})$ and $C_{e}=$ Equilibrium amount of $\mathrm{Pb}$ (II) ions

$$
\begin{gathered}
\ln K_{c}=-\Delta H^{o} / R T+\Delta S^{o} R \\
\ln K_{c}=-\Delta H^{o} / 2.303 R T+\Delta S^{o} R
\end{gathered}
$$

The $\Delta \mathrm{H}^{\circ}$ and $\Delta \mathrm{S}^{\circ}$ were obtained from the linear plot of $\ln K_{c}$ versus $1 / T$ (Figure 5). showed that pseudo second order kinetics was best fitted model \& the calculated $q_{e}$ value was in reasonable agreement with the experimental $q_{e}$ value by applying pseudosecond-order model (Table 1).

\subsection{Thermodynamics studies}

The thermodynamic parameters helps in the evaluation of spontaneous nature and heat change associated with the adsorption. The thermodynamic factors such as Gibbs free energy, entropy $\left(\Delta S^{\circ}\right) \&$ enthalpy $\left(\Delta H^{o}\right)$ were calculated according to the following equation:

(mg/L). The $\Delta H^{o}$ and $\Delta S^{o}$ were determined from the following relation:
The Gibb's free energy value represents that the process is spontaneous and feasible (Table 1). In present work, 
with increase in temperature, $\Delta G^{o}$ value became more negative indicating the increase in spontaneity of $\mathrm{Pb}(\mathrm{II})$ adsorption on PCFP surface. The positive value of $\Delta H^{o}$ and $\Delta S^{\circ}$ confirmed the endothermic process and there was increase in randomness.

(a)

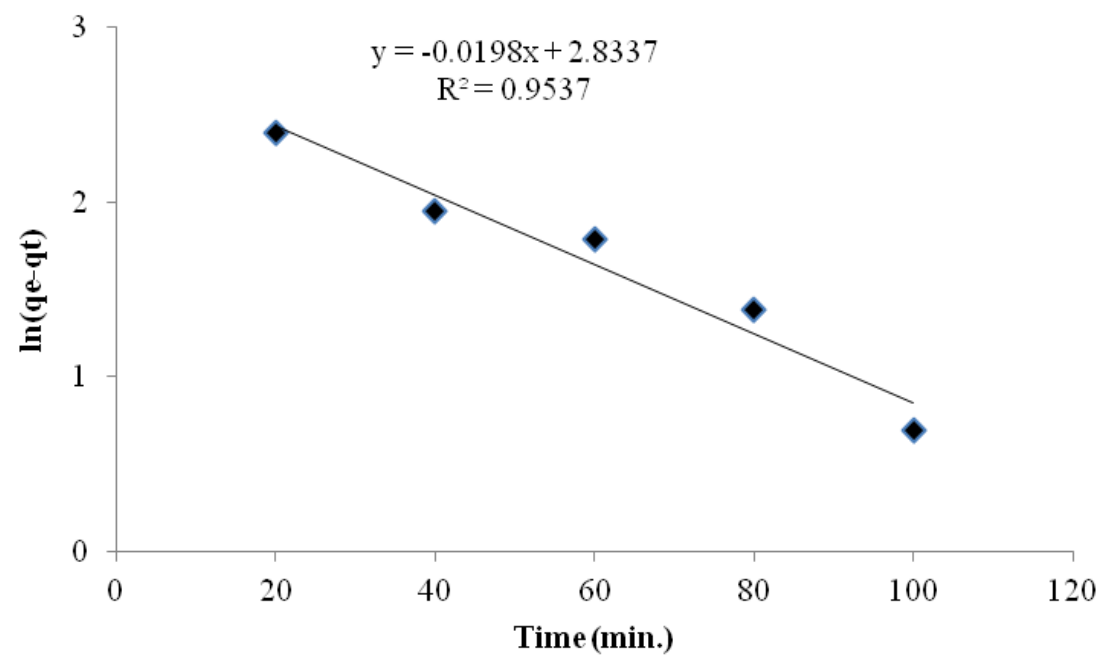

(b)

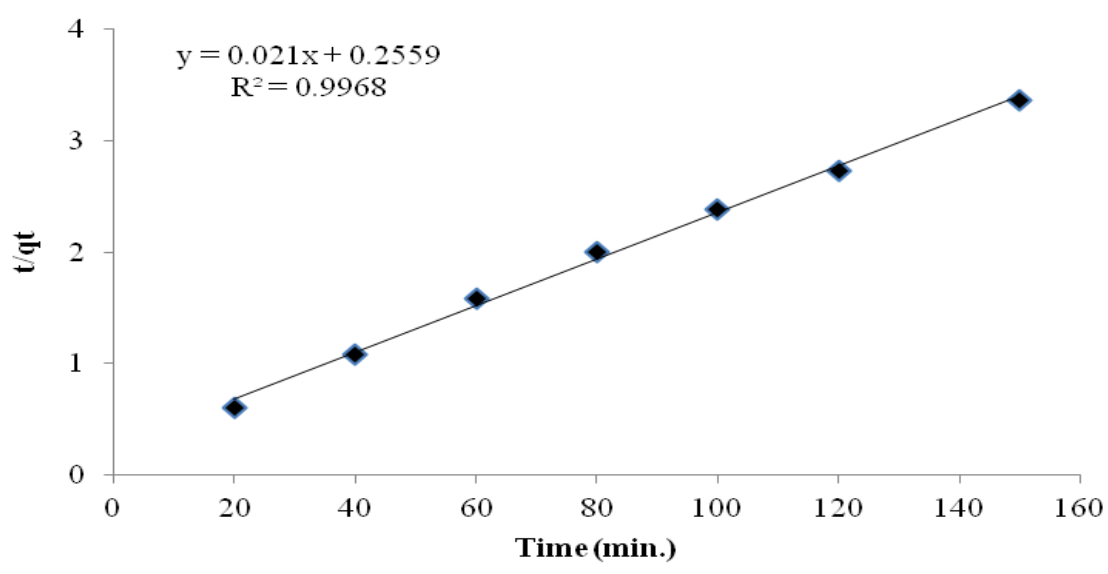

(c)

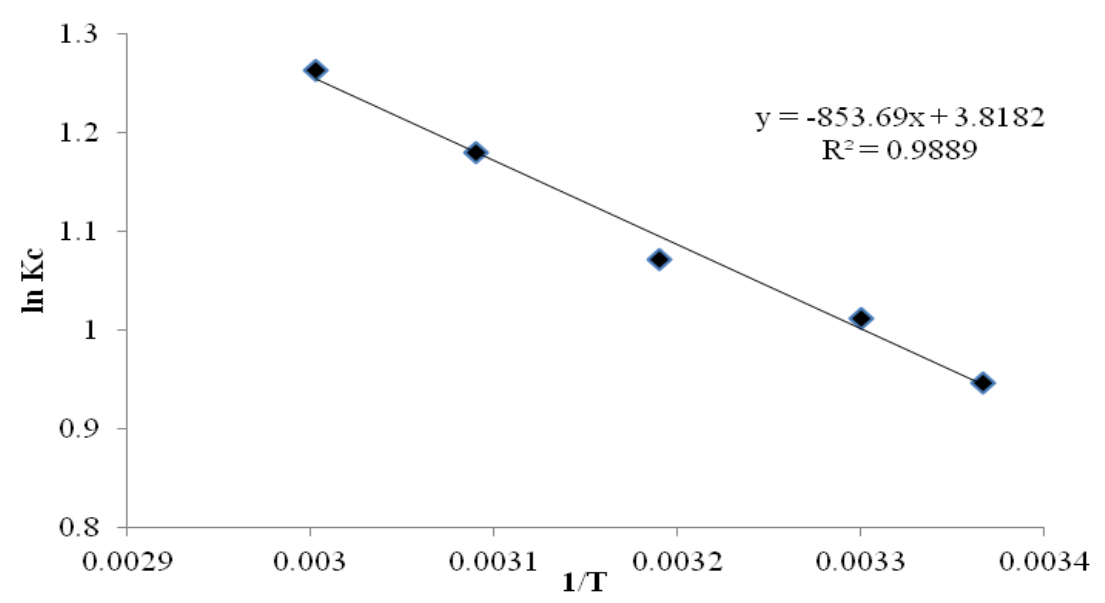

Figure 5. (a) Pseudo-first order kinetic and (b) pseudo-second order kinetic model (c) thermodynamic behavior for adsorption of lead ions onto Pavo Cristatus feather powder 
Table 1. Parameters of Isotherm models, adsorption kinetics and thermodynamics study

\section{Isotherm models}

\begin{tabular}{cccccccccc}
\hline \multicolumn{3}{c}{ Langmuir } & \multicolumn{3}{c}{ Freundlich } & \multicolumn{3}{c}{ Temkin } \\
\cline { 1 - 1 } $\begin{array}{c}\mathrm{q}_{\mathrm{max}} \\
(\mathrm{mg} / \mathrm{g})\end{array}$ & $\mathrm{K}_{\mathrm{L}}(\mathrm{l} / \mathrm{g})$ & $\mathrm{R}^{2}$ & $\mathrm{n}$ & $\mathrm{K}$ & $\mathrm{R}^{2}$ & $\mathrm{~B}$ & $\mathrm{~A}$ & $\mathrm{R}^{2}$ \\
121.95 & 0.037 & 0.997 & 1.397 & 5.633 & 0.995 & 24.626 & 0.417 & 0.981 \\
\hline
\end{tabular}

\section{Kinetics}

\begin{tabular}{ccccccc}
\hline \multicolumn{3}{c}{ Pseudo first order kinetics } & \multicolumn{5}{c}{ Pseudo second order kinetics } \\
\hline$q_{e}(\mathrm{mg} / \mathrm{g})$ & $\begin{array}{c}k_{1} \\
\left(\mathrm{~min}^{-1}\right)\end{array}$ & $R^{2}$ & $\begin{array}{c}q_{e} \\
(\mathrm{mg} / \mathrm{g})\end{array}$ & $k_{2}(\mathrm{~g} / \mathrm{mg} / \mathrm{min})$ & $R^{2}$ & $\begin{array}{c}\mathrm{q}_{\mathrm{e}}, \mathrm{exp} . \\
(\mathrm{mg} / \mathrm{g})\end{array}$ \\
16.99 & 0.0198 & 0.953 & $\mathbf{4 7 . 6 1}$ & 0.0017 & 0.996 & $\mathbf{4 4}$ \\
\hline
\end{tabular}

\begin{tabular}{|c|c|c|c|c|c|c|}
\hline \multicolumn{7}{|c|}{ Thermodynamic parameters } \\
\hline & & $\begin{array}{c}\Delta \mathrm{G}^{\mathrm{o}} \\
(\mathrm{kJ} / \mathrm{mol})\end{array}$ & & & $\begin{array}{c}\Delta \mathrm{H}^{\mathrm{o}} \\
(\mathrm{kJ} / \mathrm{mol})\end{array}$ & $\begin{array}{c}\Delta \mathrm{S}^{\mathrm{o}} \\
(\mathrm{kJ} / \mathrm{mol} / \mathrm{K})\end{array}$ \\
\hline $297 \mathrm{~K}$ & $303 \mathrm{~K}$ & $313 \mathrm{~K}$ & $323 K$ & $333 \mathrm{~K}$ & & \\
\hline-2.11 & -2.30 & -2.61 & -2.92 & -3.23 & 7.09 & 0.031 \\
\hline
\end{tabular}

3.6 Comparison of Pavo Cristatus feather with other adsorbents

A comparative study of adsorptive performance of the adsorbent used in present study, i.e PFCP and other naturally occurring adsorbents already reported in literature was carried out. On analysis, it was noticed that the maximum capacity $\left(\mathrm{q}_{\max }\right)$ of PFCP i.e $121.95 \mathrm{mg} / \mathrm{g}$ is superior to almost all previous report. This comparison also indicated highest adsorption efficiency of the PFCP for removal of $\mathrm{Pb}(\mathrm{II})$ ions from aqueous medium (Table 2) makes it very good candidate for water treatment . 
Table 2. Comparison of Pavo Cristatus feather and other adsorbents for adsorption of lead ions from water/wastewater samples.

\begin{tabular}{|c|c|c|c|c|c|c|c|c|}
\hline Adsorbent & Preparation method & $q_{\max }(\mathrm{mg} / \mathrm{g})$ & $\begin{array}{c}\text { Other } \\
\text { target metal } \\
\text { ions }\end{array}$ & $\begin{array}{l}\text { Temp. } \\
(\mathbf{K})\end{array}$ & pH & $\begin{array}{l}\text { Reg. coeff. } \\
\qquad\left(R^{2}\right)\end{array}$ & Isotherms/ kinetics & Ref. \\
\hline Rice husk & commercially available & 1.41 & NA & NA & $4-5$ & 0.832 & Langmuir & Raikar et al., 2015 \\
\hline Alluvial soil & commercially available & 1.567 & NA & 313 & 6 & 0.918 & Langmuir & Das et al., 2014 \\
\hline $\begin{array}{c}\text { Orange and banana } \\
\text { peel }\end{array}$ & Commercially available & $\begin{array}{l}7.75 \text { and } \\
7.97\end{array}$ & NA & NA & 5.5 & $\begin{array}{c}0.963 \\
\text { and } 0.969\end{array}$ & Langmuir & $\begin{array}{l}\text { Annadurai et al., } \\
2002\end{array}$ \\
\hline Pomegranate peel & commercially available & 13.87 & NA & NA & $5.6-7.6$ & 0.999 & $\begin{array}{c}\text { Langmuir/ } \\
\text { Pseudosecond- order }\end{array}$ & $\begin{array}{l}\text { El-Ashtoukhy et al., } \\
2008\end{array}$ \\
\hline Ficus carcia leaves & commercially available & 37.74 & $\mathrm{Cd}$ & 293 & 5 & 0.999 & $\begin{array}{c}\text { Langmuir/ } \\
\text { Pseudosecond- order }\end{array}$ & Farhan et al., 2013 \\
\hline $\begin{array}{l}\text { Diceriocaryum } \\
\text { eriocarpum }\end{array}$ & commercially available & 41.49 & NA & 298 & NA & 0.966 & Langmuir & $\begin{array}{c}\text { Edokpayi et al., } \\
2015\end{array}$ \\
\hline Sago waste & Commercially available & 46.6 & $\mathrm{Cu}$ & NA & 4.5 & 0.98 & $\begin{array}{c}\text { Langmuir/ } \\
\text { Pseudosecond- order }\end{array}$ & Quek et al., 1998 \\
\hline Dried water hyacinth & leaves and stem & 66.6 and 90.5 & NA & 298 & 5 & $\begin{array}{c}0.999 \text { and } \\
0.999\end{array}$ & $\begin{array}{l}\text { Langmuir/ } \\
\text { Pseudosecond- order }\end{array}$ & El-Wakil et al., 2014 \\
\hline Sphagnum moss peat & peat 1 , peat 2 , peat 3 & $\begin{array}{c}87.22,92.77 \\
\text { and } 80.61\end{array}$ & NA & NA & 6 & NA & Langmuir & Bulgariu et al., 2009 \\
\hline $\begin{array}{l}\text { Manganoxide } \\
\text { minerals }\end{array}$ & commercially available & 98 & $\mathrm{Cd}$ & 318 & NA & 0.999 & $\begin{array}{c}\text { Langmuir/ } \\
\text { Pseudosecond- order }\end{array}$ & $\begin{array}{l}\text { Sonmezay et al., } \\
2012\end{array}$ \\
\hline Pomegranate biomass & Commercially available & 111.5 & NA & NA & 4.5 & 0.963 & Langmuir & Alam et al., 2012 \\
\hline Orange barks & commercially available & 112.4 & NA & 298 & $3-4.6$ & 0.950 & Langmuir & $\begin{array}{c}\text { Azouaoua et al., } \\
2013\end{array}$ \\
\hline $\begin{array}{l}\text { Pavo Cristatus } \\
\text { feather }\end{array}$ & commercially available & 121.95 & NA & 310 & 6 & 0.997 & $\begin{array}{c}\text { Langmuir/ } \\
\text { Pseudosecond- order }\end{array}$ & This study \\
\hline
\end{tabular}




\subsection{Statistical analysis}

RSM is a statistical and mathematical tool for maximizing the responses by optimizing the operational variables (Saini et a1., 2019; Kaur et al., 2019). BBD was applied to study the lead ions adsorption onto PCFP. Design Expert ${ }^{\circledR}$ software was used to design the experiments and regression model. Solution $\mathrm{pH}$, initial concentration, contact time \& temperature were selected as independent input variables (Table 3). Coded $\&$ actual terms for the selected input variables factors are shown in table3. Table 4 shows the experimental and predicted values of lead ions uptake onto Pavo Cristatus feather powder. The \% removal of 67.14 for lead ions was noted at central points of all factors viz., $\mathrm{pH} 6$, initial concentration $60 \mathrm{ppm}$, contact time $70 \mathrm{~min}$ and temperature $40{ }^{\circ} \mathrm{C}$.The optimal parameters for maximum \% removal of $\mathrm{Pb}$ (II) $(81.4712 \%)$ were obtained at $\mathrm{pH}$ 6.31, initial concentration of $43.79 \mathrm{mg} / \mathrm{L}$, contact time 119.51 minutes \& temperature $59.67^{\circ} \mathrm{C}$.

Table 3. Actual and coded values of different process parameters of lead ions

\begin{tabular}{lccc}
\hline \multicolumn{1}{c}{ Factors } & Low(-1) & Mid(0) & High(+1) \\
\hline $\mathrm{pH}(\mathrm{A})$ & 3 & 6 & 9 \\
initial ion concentration (B) & 20 & 60 & 100 \\
contact time (C) & 20 & 70 & 120 \\
Temperature (D) & 20 & 40 & 60 \\
\hline
\end{tabular}

\subsubsection{Adequacy of the model}

Design expert software confirmed that the quadratic model was a significant model for PCFP. The analysis of variance (ANOVA) was applied to validate the relevancy of the model (Table 5). The $\mathrm{R}^{2}$ value for lead ions was 0.993 , respectively. The quadratic model was a significant model for lead ions adsorption from water by PCFP. Quadratic model could not explain $0.6805 \%$ of variations for lead ions. The predicted $\mathrm{R}^{2}(0.9608)$ are in good accord with the adjusted $\mathrm{R}^{2}(0.986)$ for $\mathrm{Pb}$ (II) ions. Adequate precision ratio greater than 4 is required for adequate signal. Table 5 showed that the signal to noise ratio is 45.959 for $\mathrm{Pb}(\mathrm{II})$ ions.

Table 4. Experimental and predicted values of lead ions uptake onto Pavo Cristatus feather powder

\begin{tabular}{ccccccc}
\hline Run & A & B & C & D & $\begin{array}{c}\text { Experimental \% } \\
\text { removal }\end{array}$ & $\begin{array}{c}\text { Predicted \% } \\
\text { removal }\end{array}$ \\
\hline 1 & 0 & 0 & 0 & 0 & 67.16 & 67.16 \\
2 & 0 & -1 & -1 & 0 & 44.50 & 45.85 \\
3 & 0 & -1 & 1 & 0 & 75.67 & 75.30 \\
4 & 1 & 1 & 0 & 0 & 45.00 & 43.68 \\
5 & 1 & 0 & 1 & 0 & 62.16 & 63.97 \\
6 & -1 & 0 & 0 & -1 & 42.80 & 43.70 \\
7 & 1 & 0 & 0 & 1 & 58.60 & 58.54 \\
8 & 1 & 0 & 0 & -1 & 41.16 & 40.40 \\
9 & 0 & 0 & -1 & 1 & 58.60 & 57.55 \\
10 & 0 & 1 & 1 & 0 & 64.00 & 63.49 \\
11 & 0 & 0 & -1 & -1 & 44.33 & 44.66 \\
12 & 0 & 1 & 0 & 1 & 65.20 & 66.00
\end{tabular}




\begin{tabular}{ccccccc}
13 & 0 & -1 & 0 & -1 & 55.15 & 53.90 \\
14 & 0 & 0 & 0 & 0 & 67.16 & 67.16 \\
15 & 0 & -1 & 0 & 1 & 65.70 & 65.13 \\
16 & 0 & 0 & 1 & -1 & 62.45 & 63.08 \\
17 & -1 & -1 & 0 & 0 & 46.20 & 47.10 \\
18 & 0 & 0 & 1 & 1 & 81.30 & 80.55 \\
19 & 1 & 0 & -1 & 0 & 36.70 & 37.096 \\
20 & -1 & 0 & 0 & 1 & 54.33 & 55.92 \\
21 & -1 & 0 & 1 & 0 & 58.99 & 58.13 \\
22 & -1 & 1 & 0 & 0 & 48.00 & 47.67 \\
23 & -1 & 0 & -1 & 0 & 45.85 & 43.59 \\
24 & 1 & -1 & 0 & 0 & 50.50 & 50.41 \\
25 & 0 & 0 & 0 & 0 & 67.16 & 67.16 \\
26 & 0 & 1 & -1 & 0 & 50.30 & 51.51 \\
27 & 0 & 0 & 0 & 0 & 67.16 & 67.16 \\
28 & 0 & 1 & 0 & -1 & 46.76 & 46.88 \\
29 & 0 & 0 & 0 & 0 & 67.16 & 67.16 \\
\hline
\end{tabular}

Table 5. Analysis of variance table and statistics of lead ions adsorption

\begin{tabular}{cccccc}
\hline \multicolumn{5}{c}{ Variance table } \\
\hline Source & Sum of squares & df & Mean Square & F value & $\begin{array}{c}\text { p-value } \\
\text { Prob > F }\end{array}$ \\
\hline Model & 3532.463 & 14 & 252.3188 & 145.9403 & $<0.0001$ \\
A & 0.350208 & 1 & 0.350208 & 0.202559 & 0.6596 \\
B & 28.39763 & 1 & 28.39763 & 16.42509 & 0.0012 \\
C & 1287.334 & 1 & 1287.334 & 744.589 & $<0.0001$ \\
D & 691.2972 & 1 & 691.2972 & 399.8437 & $<0.0001$ \\
AB & 13.3225 & 1 & 13.3225 & 7.705684 & 0.0149 \\
AC & 37.9456 & 1 & 37.9456 & 21.94759 & 0.0004 \\
AD & 8.732025 & 1 & 8.732025 & 5.050571 & 0.0413 \\
BC & 76.30023 & 1 & 76.30023 & 44.13177 & $<0.0001$ \\
BD & 15.56303 & 1 & 15.56303 & 9.001596 & 0.0095 \\
CD & 5.2441 & 1 & 5.2441 & 3.033168 & 0.1035 \\
$\mathrm{~A}^{2}$ & 1296.447 & 1 & 1296.447 & 749.8601 & $<0.0001$ \\
$\mathrm{~B}^{2}$ & 218.2995 & 1 & 218.2995 & 126.2636 & $<0.0001$ \\
$\mathrm{C}^{2}$ & 34.83766 & 1 & 34.83766 & 20.14997 & 0.0005 \\
$\mathrm{D}^{2}$ & 73.93988 & 1 & 73.93988 & 42.76655 & $<0.0001$ \\
\hline
\end{tabular}




\section{Model summary statistics of lead ions adsorption}

\begin{tabular}{cccc}
\hline Std. Dev. & 1.314883 & R-Squared & 0.993195 \\
Mean & 56.55345 & Adj R-Squared & 0.986389 \\
C.V. \% & 2.325028 & Pred R-Squared & 0.960800 \\
PRESS & 139.42 & Adeq Precision & 45.95964 \\
\hline
\end{tabular}

The final quardatric equation in terms of coded variables is given below:

$\%$ removal $(\mathrm{Pb}) \quad=\quad 67.16-0.1708 \mathrm{~A}-1.5383 \mathrm{~B}+10.3575 \mathrm{C}+7.59 \mathrm{D}-$

$1.825 \mathrm{AB}+3.08 \mathrm{AC}+1.4775 \mathrm{AD}-4.3675 \mathrm{BC}+1.9725 \mathrm{BD}+1.145 \mathrm{CD}-14.1375 \mathrm{~A}^{2}-5.80125 \mathrm{~B}^{2}-$

$2.3175 \mathrm{C}^{2}-3.37625 \mathrm{D}^{2}$

(a)

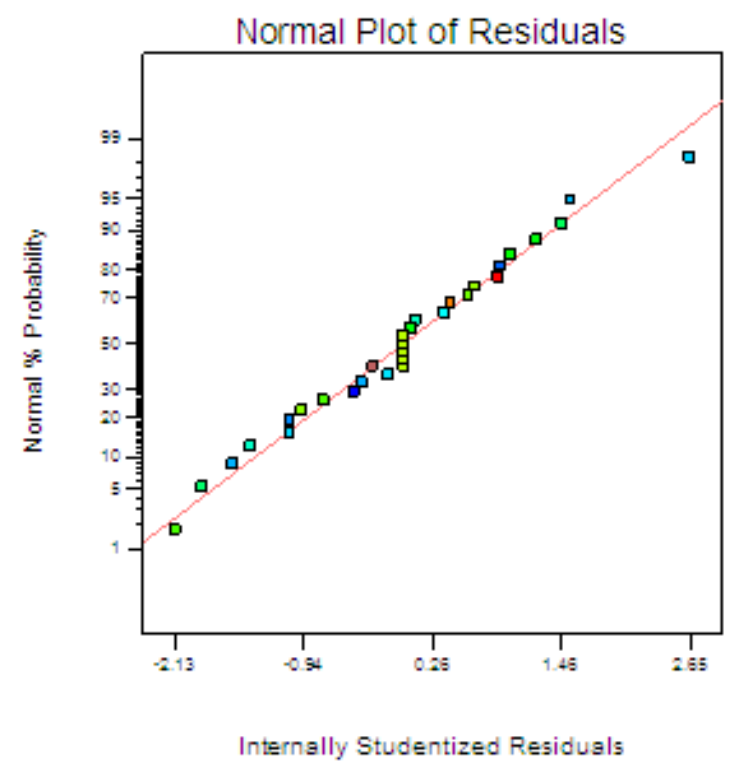

(b)

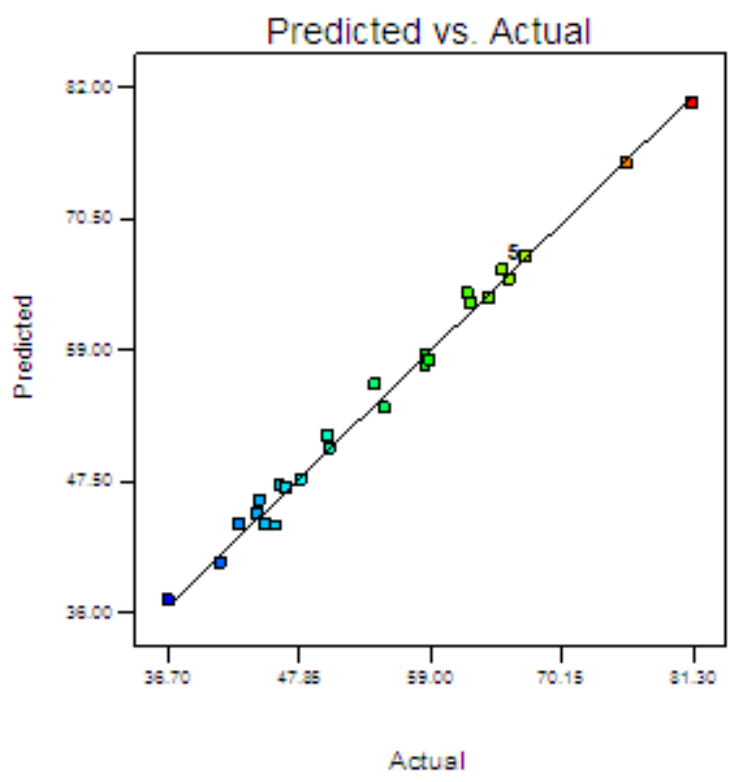


(c)
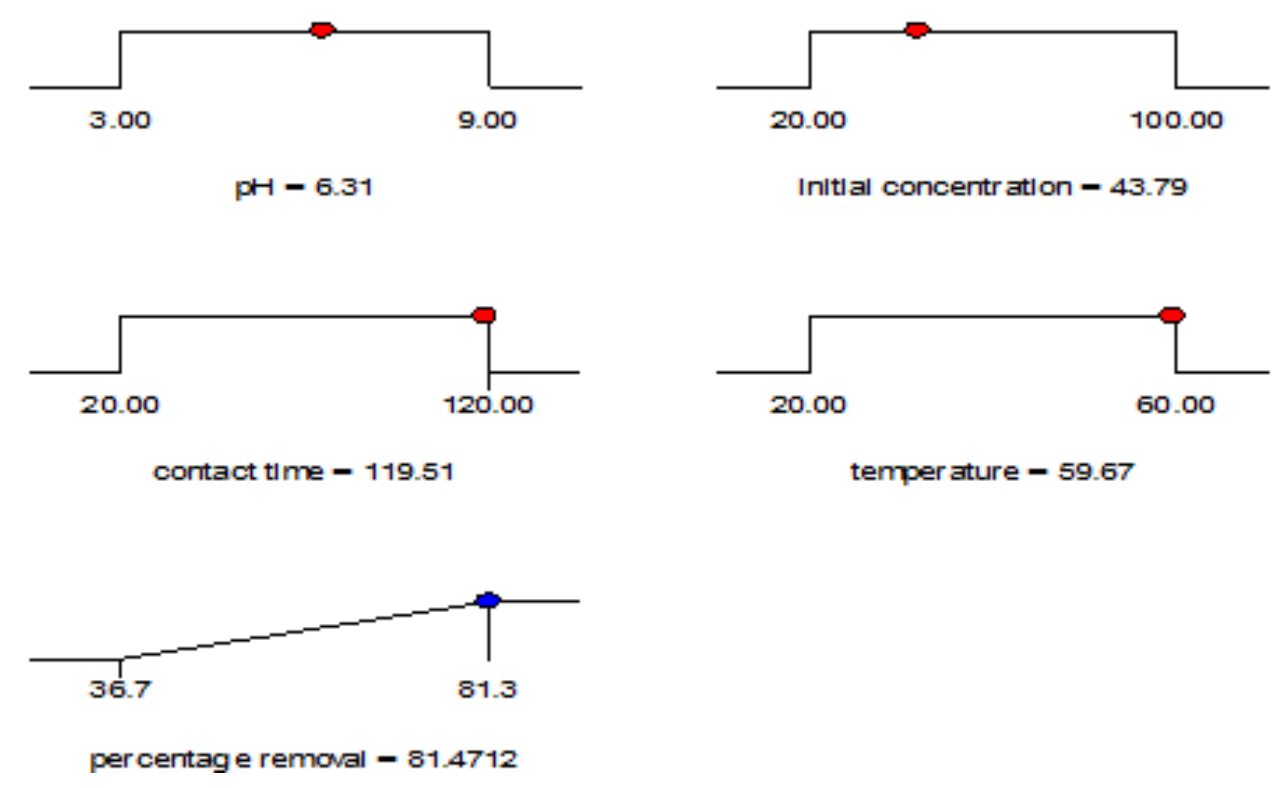

Figure 6. (a) Normal plot of residuals and (b) Predicted vs actual plot (c) desirability ramps of lead ions adsorption onto Pavo Cristatus feather powder

\subsubsection{Interactive effects of different parameters on percentage removal}

Figure $6 \quad(\mathrm{a} \& \mathrm{~b})$ represents the normal plot of residuals and the plot between experimental \& predicted \% removal value of lead ions adsorption onto PCFP. The suitability of the model was indicated by the data points spread near the straight line. Data points around the line in Figure 6 confirm that the predictions are close to the observed values.

The contour plots and three dimensional (3-d) plots shows the interactions between the two independent variables \& their influence on the response. The 3-d plots of \% removal of lead ions versus initial concentration, temperature, contact time and $\mathrm{pH}$ are given in Figure 7 (a-f) for PCFP.

Figure 7 (a-f) represents the relationship between percentage removal and independent variables. The simultaneous effect of two variables ( $\mathrm{pH} /$ contact time, $\mathrm{pH}$ /initial concentration,
$\mathrm{pH} \quad$ /temperature, initial concentration/temperature, initial concentration/contact time \& contact time/temperature on percentage removal at fixed adsorbent dose is shown in Figure 7. The shape of the curves in Figure 7(a) to (f) indicates good interaction of the variables at fixed adsorbent dose of $20 \mathrm{mg} / \mathrm{L}$. Desirability function was applied in numerical optimization to find out optimum conditions for maximum removal of $\mathrm{Pb}$ (II) while taking care of all variables at fixed adsorbent dose of $20 \mathrm{mg} / \mathrm{L}$. The desirability function is a technique for the simultaneous determination of optimal settings of input factors that can determine optimal performance levels for one or more responses. Desirable values for input variables and response can be selected from the given input optimizations. The input factors were given specific values from the given input optimizations. The optimal parameters for maximum \% removal of $\mathrm{Pb}$ (II) $(81.47 \%)$ were obtained at $\mathrm{pH} 6.31$, initial lead ion concentration of 43.79 $\mathrm{mg} / \mathrm{L}$, contact time 119.51 minutes \& temperature $59.67{ }^{\circ} \mathrm{C}$ (Figure 6). 
(a)

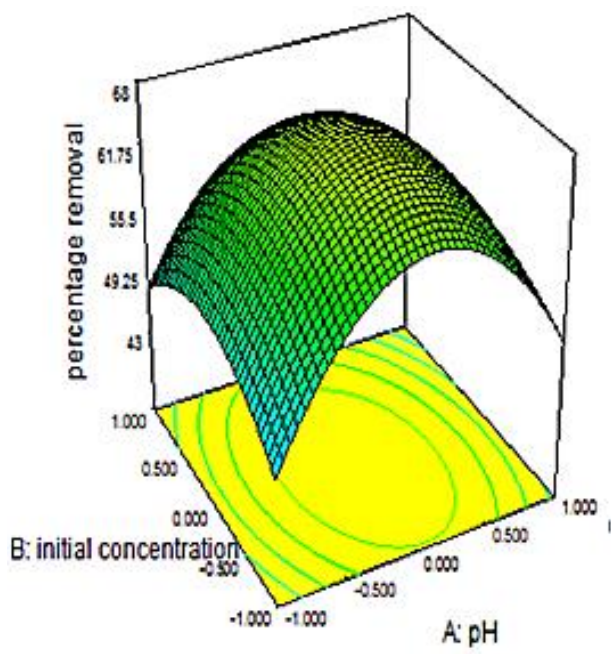

(c)

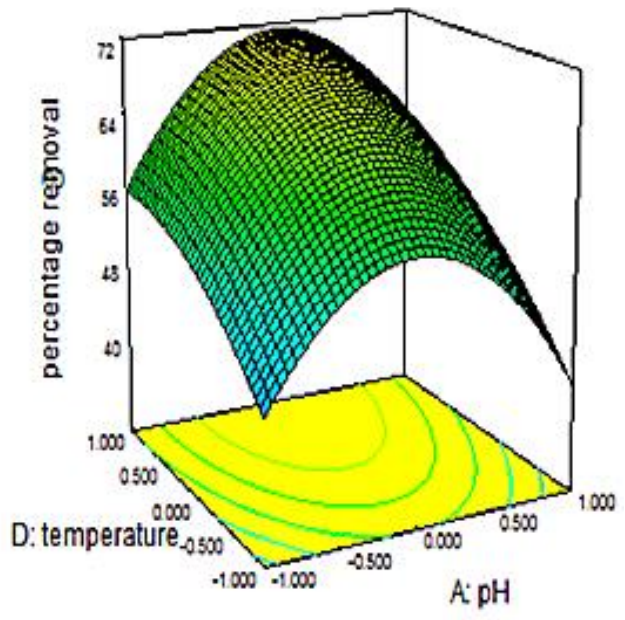

(e)

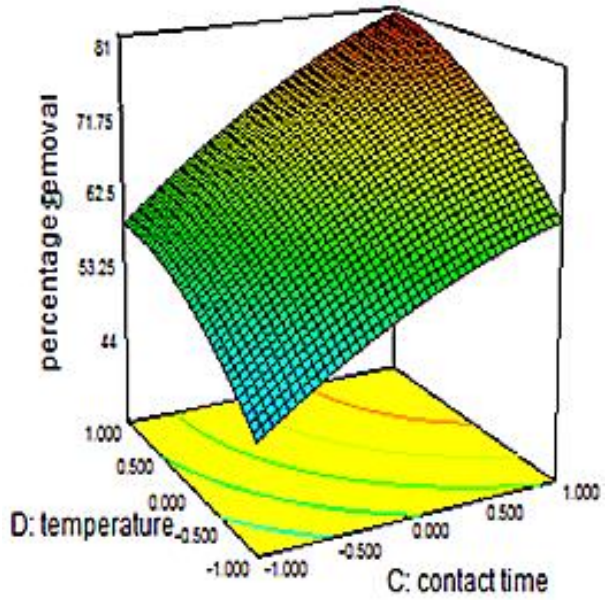

(b)

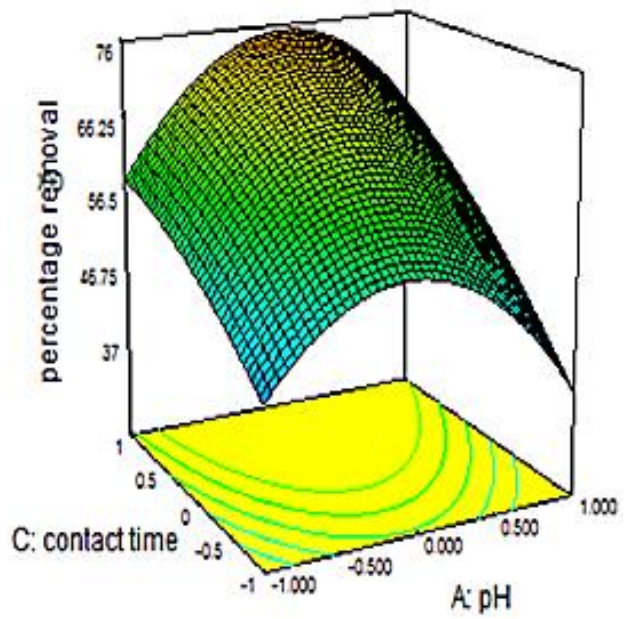

(d)

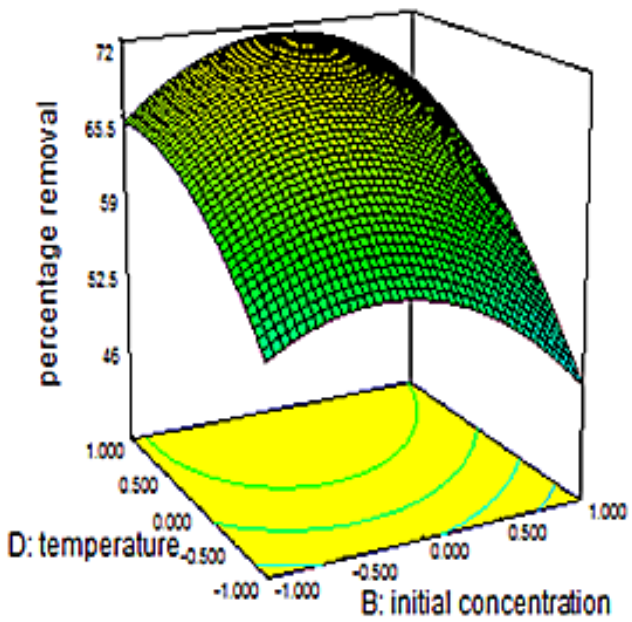

(f)

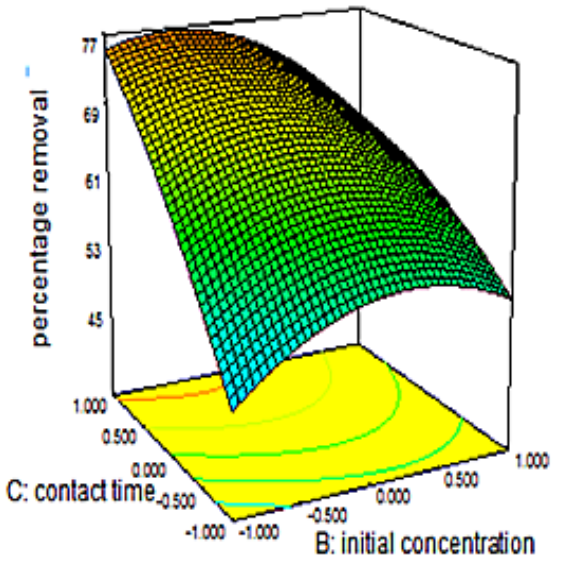

Figure 7. Response surface plots showing the effect of independent input variables on lead ions adsorption onto Pavo Cristatus feather powder. 


\section{CONCLUSIONS}

The SEM and the EDX, BET and FTIR studies confirmed the chemical adsorption of leads ions onto PCPF due to the formation of new chemical bond between metal ions and carboxylate group generated by the loss of proton on the surface. The results of batch studies showed that lead removal rely on the temperature, initial concentration of $\mathrm{Pb}(\mathrm{II}), \mathrm{pH} \&$ contact time. Optimal values obtained from batch studies for lead adsorption onto PCPF were $\mathrm{pH} 6$; adsorbent dose $20 \mathrm{mg} / \mathrm{L}$; temperature $303 \mathrm{~K}$ and contact time 120 minutes. Adsorption isotherms and kinetic studies showed that lead ions adsorption onto Pavo Cristatus feather followed the Langmuir model indicating monolayer adsorption. Langmuir maximum removal efficiency was $121.95 \mathrm{mg} / \mathrm{g}$. BBD was applied to study the interactive effects of parameters on removal percentage and to optimize various parameters for $\mathrm{Pb}$ (II) adsorption onto PCFP from solution. The predicted and experimental values of removal percentage obtained at various conditions confirmed good agreement with reasonably little error. The optimal parameters for maximum \% removal of lead (81.4712) were obtained at initial lead (II) ion concentration of $43.79 \mathrm{mg} / \mathrm{L}$, $\mathrm{pH}$ 6.31, contact time 119.51 minutes and temperature $59.67{ }^{\circ} \mathrm{C}$. The results indicate that Pavo Cristatus feather shows good adsorption behavior for lead and can be used as a viable and economic adsorbent.

\section{ACKNOWLEDGEMENT}

The authors are thankful to the administration and management of Manav Rachna International Institute of Research and Studies, Faridabad, India, for providing infrastructure and other support in carrying out the research work.

\section{CONFLICT OF INTEREST}

The authors declare that they do not have any conflict of interest.

\section{REFERENCES}

Akpomie, G. K., Abuh, M. A., Obi, N. D., Nwafor, E. C., Ekere, P. O., \& Onyiah, I. M. (2013). Modeling on the equilibrium, kinetics and thermodynamics of zinc (II) ions removal from solution by. Aloji" kaolinite clay", Int. J. Basic Appl. Sci, 2, 173-185.

Alam, M., Nadeem, R., \& Jilani, M. I. (2012). $\mathrm{Pb}$ (II) removal from wastewater using Pomegranate waste biomass. International Journal of chemical and Biochemical sciences, 1(2012), 2429.

Annadurai, G., Juang, R. S., \& Lee, D. J. (2003). Adsorption of heavy metals from water using banana and orange peels. Water science and technology, 47(1), 185-190.

Azouaoua, N., Belmedanib, M., Mokaddema, H., \& Sadaoui, Z. (2013). Adsorption of lead from aqueous solution onto untreated orange barks. Chemical Engineering Transactions, 32.

BIS (1981). Tolerance limits for industrial effluents prescribed by Bureau of Indian Standards. IS 2490 (Part I), New Delhi.

Brunauer, S., Emmett, P. H., \& Teller, E. (1938). Adsorption of gases in multimolecular layers. Journal of the American chemical society, 60(2), 309-319. 
Bulgariu, L., Robu, B., \& Macoveanu, M. (2009). The $\mathrm{Pb}$ (II) sorption from aqueous solutions by sphagnum moss peat. Revista de Chimie, 60(2), 171-175.

Business Standard (2018). High amounts of heavy metals in ground water in Delhi's Krishna Vihar: Research. http://www.business-

standard.com/article/pti-

stories/high-amounts-of-heavy-

metals-in-ground-water-in-delhi-s-

krishna-vihar-research-

118031200945_1.html/.

CNN (2016). Michigan governor apologizes for Flint water crisis. http://edition.cnn.com/2016/01/07/ us/flint-michigan-water-governormayor-meeting/.

Das, B., Mondal, N. K., Bhaumik, R., \& Roy, P. (2014). Insight into adsorption equilibrium, kinetics and thermodynamics of lead onto alluvial soil. International Journal of Environmental Science and Technology, 11(4), 1101-1114.

Edokpayi, J. N., Odiyo, J. O., Msagati, T. A., \& Popoola, E. O. (2015). A Novel Approach for the removal of lead (II) ion from wastewater using mucilaginous leaves of diceriocaryum eriocarpum plant. Sustainability, 7(10), 1402614041.

El-Ashtoukhy, E. S., Amin, N. K., \& Abdelwahab, O. (2008). Removal of lead (II) and copper (II) from aqueous solution using pomegranate peel as a new adsorbent. Desalination, 223(1-3), 162-173.

El-Wakil, A. M., Abou El-Maaty, W. M., \& Awad, F. S. (2014). Removal of lead from aqueous solution on activated carbon and modified activated carbon prepared from dried water hyacinth plant. J Anal Bioanal Tech, 5(2), 1-14.

EPA (2008). The provision and quality of drinking water in Ireland: a report for the year. Environmental Protection Agency, 102, 1-24.

Farhan, A. M., Al-Dujaili, A. H., \& Awwad, A. M. (2013). Equilibrium and kinetic studies of cadmium (II) and lead (II) ions biosorption onto Ficus carcia leaves. International Journal of Industrial Chemistry, 4(1), 24.

Garba, Z. N., Bello, I., Galadima, A., \& Lawal, A. Y. (2016). Optimization of adsorption conditions using central composite design for the removal of copper (II) and lead (II) by defatted papaya seed. Karbala International Journal of Modern Science, 2(1), 20-28.

Kamsonlian, S., \& Shukla, B. (2013). Optimization of process parameters using response surface methodology (RSM): removal of $\mathrm{Cr}$ (VI) from aqueous solution by wood apple shell activated carbon (WASAC). Research Journal of Chemical Sciences, 3, 31-37.

Kaur, I., Gupta, A., Singh, B. P., Kumar, R., \& Chawla, J. (2019). Defluoridation of water using micelle templated MCM-41: adsorption and RSM studies. Journal of Water Supply: Research and TechnologyAqua, 68(4), 282-294.

Kotrannavar, V., Sarashetty, R., \& Kanthi, V. (2012). Physico-chemical analysis of Mayūrapuccha Bhasma prepared by two methods. Ancient science of life, 32(1), 45. 
Kyzas, G. Z., Terzopoulou, Z., Nikolaidis, V., Alexopoulou, E., \& Bikiaris, D. N. (2015). Low-cost hemp biomaterials for nickel ions removal from aqueous solutions. Journal of Molecular Liquids, 209, 209-218.

Naseem, R., \& Tahir, S. S. (2001). Removal of $\mathrm{Pb}$ (II) from aqueous/acidic solutions by using bentonite as an adsorbent. Water Research, 35(16), 3982-3986.

Niad, M., Zaree, S., \& Tahanzadeh, N. (2016). Response surface methodology for optimization of Cd (II) biosorption by Cystoseria myricaas. J Biomed, 1(2), e6264.

Quek, S. Y., Wase, D. A. J., \& Forster, C. F. (1998). The use of sago waste for the sorption of lead and copper. Water Sa, 24(3), 251-256.

Raikar, R. V., Correa, S., \& Ghorpade, P. (2015). Removal of lead (II) from aqueous solution using natural and activated rice husk. International Research Journal of Engineering and Technology, 2(03), 16771685 .

Saini, S., Kumar, R., Chawla, J., \& Kaur, I. (2019). Adsorption of bivalent lead ions from an aqueous phase system: Equilibrium, thermodynamic, kinetics, and optimization studies. Water Environment Research, 91(12), 1692-1704.

Soenmezay, A., Öncel, M. S., \& Bektaş, N. (2012). Adsorption of lead and cadmium ions from aqueous solutions using manganoxidem minerals.

Transactions of Nonferrous Metals Society of China, 22(12), 31313139.

South China Morning Post (2015). Hong kong tainted water scare. http://www.scmp.com/topics/hong -kong-tainted-water-scare/

The Times of India (2013). Kolkata lead poisoning affects 20 Kolkata kids. http://timesofindia.indiatimes.com /city/kolkata/Lead-poisoningaffects-20-Kolkatakids/articleshow/21062303.cms.

The Tribune (2018). State groundwater most contaminated. http://www.tribuneindia.com/news /punjab/state-groundwater-mostcontaminated/539909.html/

The Wall Street Journal (2015). An unlikely source of lead poisoning indias idols. https://blogs.wsj.com/indiarealtim e/2015/06/04/an-unlikely-sourceof-lead-poisoning-indias-idols/

WHO (1996). Guidelines for drinking water and wastewater quality. Health criteria and other supporting information, Geneva, 2, 152-279.

Yavuz, O., Guzel, R., Aydın, F., Tegin, İ., \& Ziyadanoğulları, R. (2007). Removal of cadmium and lead from aqueous solution by calcite, $16,467-471$. 